\title{
The prevalence and prognostic and clinicopathological value of PD-L1 and PD-L2 in renal cell carcinoma patients: a systematic review and meta-analysis involving 3,389 patients
}

\author{
Yi Lu ${ }^{1}$, Yuxuan Song ${ }^{1}$, Yawei $\mathrm{Xu}^{1}$, Ningjing Ou${ }^{1}$, Zhen Liang ${ }^{1}$, Rui Hu${ }^{1}$, Wei Zhang ${ }^{1}$, Jiaqi Kang ${ }^{1}$, \\ Xianhao Wang ${ }^{1}, \mathrm{Li} \mathrm{Liu}^{2}$, Yongjiao Yang ${ }^{2}$, Xiaoqiang Liu ${ }^{1}$ \\ ${ }^{1}$ Department of Urology, Tianjin Medical University General Hospital, Tianjin 300052, China; ${ }^{2}$ Department of Urology, The Second Hospital of \\ Tianjin Medical University, Tianjin 300211, China \\ Contributions: (I) Conception and design: Y Lu, Y Song; (II) Administrative support: X Liu; (III) Collection and assembly of data: Y Song, Y Lu, X \\ Wang, J Kang, Y Xu; (IV) Data analysis and interpretation: N Ou, Z Liang, W Zhang, Y Song, L Liu, Y Yang; (V) Manuscript writing: All authors; (VI) \\ Final approval of manuscript: All authors. \\ Correspondence to: Xiaoqiang Liu. Department of Urology, Tianjin Medical University General Hospital, 154 Anshan Road, Heping District, Tianjin \\ 300052, China. Email: luis_will@126.com.
}

Background: The research of the prognostic and clinicopathologic values of programmed cell death ligand 1/2 (PD-L1/2) in renal cell carcinoma (RCC) patients has been mired by a dearth of studies and considerable controversy. We thus conducted a systematic review and meta-analysis to report the prevalence and prognostic and clinicopathological value of programmed cell death ligand 1 (PD-L1) and programmed cell death-legend 2 (PD-L2) in RCC patients.

Methods: The PubMed, Cochrane Library, EMBASE databases were searched to find human studies limited to English language literature published through October 1, 2019. Using random or fixed effects models, hazard ratios (HRs) and 95\% confidence intervals (CIs) were evaluated to explore the prognostic value of PD-Ls expression, while odds ratios (ORs) and 95\% CIs were evaluated to investigate clinicopathological parameters. The protocol of the study was registered in PROSPERO (CRD42019135199).

Results: After pooling all 16 eligible studies comprising 3,389 patients, we found that the overall prevalence of PD-L1 and PD-L2 in RCC patients was 27\% and 39\%, respectively. Furthermore, PD-L1 over-expression was a strong negative predictor for overall survival (OS), disease-free survival/progression-free survival (DFS/ PFS), and cancer-specific survival (CSS) in renal cell carcinoma patients (HR =2.86, 95\% CI: 1.83-4.47, $\mathrm{P}<0.001$; HR =2.64, 95\% CI: 1.99-3.52, $\mathrm{P}<0.001$; HR =2.78, 95\% CI: 2.17-3.56, $\mathrm{P}<0.001)$. Meanwhile, PDL2 over-expression was only a weak negative predictor for CSS (HR =1.66, 95\% CI: 1.05-2.65, P<0.05). Subgroup analysis showed that Caucasians had worse OS (HR =3.60, 95\% CI: 1.77-7.33, P<0.001), PFS (HR $=3.56,95 \%$ CI: 2.44-5.18, $\mathrm{P}<0.001$ ), and CSS (HR =3.13, 95\% CI: 2.37-4.14, $\mathrm{P}<0.001)$ than Asians. PD-L1 was a strong indicator for worse prognosis $(\mathrm{P}<0.05$ for all), while PD-L2 over-expression was only associated with sarcomatoid features (presence $v s$. absence, $\mathrm{OR}=1.80,95 \% \mathrm{CI}: 1.13-2.86, \mathrm{P}=0.014$ ). Notably, PD-L1 overexpression was more prevalent in women (male $v$ s. female, $\mathrm{OR}=0.68,95 \% \mathrm{CI}$ : $0.51-0.90, \mathrm{P}=0.006$ ).

Conclusions: Higher PD-L1 expression is more closely associated with poor prognosis and more advanced clinicopathological features in RCC patients than PD-L2, especially in women and Caucasian patients. PDL2 was a weak negative predictor of poor CSS of RCC and was not a prompt for the metastasis of RCC.

Keywords: Immune checkpoint; prognostic biomarker; programmed cell death ligand 1 (PD-L1); programmed cell death-legend 2 (PD-L2); renal cell carcinoma (RCC)

Submitted Oct 15, 2019. Accepted for publication Jan 05, 2020.

doi: $10.21037 /$ tau.2020.01.21

View this article at: http://dx.doi.org/10.21037/tau.2020.01.21 


\section{Introduction}

As one of the most common malignancies of the kidney, renal cell carcinoma (RCC) is not only estimated to be the $16^{\text {th }}$ most common cancer in the world but also causes approximately 175,000 deaths worldwide each year (1). Clear cell RCC (ccRCC), the most common histological type of RCC, and accounts for the majority of RCC deaths (2). Half of RCC cases will eventually progress to metastatic RCC (mRCC) if not treated with a proper intervention $(3,4)$.

Over the past decade, the mechanisms underlying the etiology and pathogenesis of tumors, along with immune checkpoint inhibitory programmed cell death (PD-1)/ programmed cell death ligand 1 (PD-L1) blockadeone of the most representative breakthroughs in tumor immunology—have been extensively discussed $(5,6)$. Different from other tumors, RCC can not only be treated with surgery, chemotherapy, and radiotherapy but also with immunotherapy, yielding significantly positive treatment outcomes (7). Anti-PD-1/PD-L1 drugs have been approved by the Food and Drug Administration (FDA) and have been widely used in clinical practice as they can strengthen antitumor immunity and promote immune suppression in the tumor microenvironment (8-11). It has been reported that PD-1 has 2 ligands, PD-L1 and PD-L2 (12). While PD-1/ PD-L1 has been widely and comprehensively studied, with PD-L1 being assumed to have associations with poor prognosis in several types of cancers (13), PD-L2 has drawn little attention, and its function is still unclear.

Both PD-L1 and PD-L2 play a suppressive role in T cell proliferation and cytokine release by interacting with PD-1 (12). According to a number of studies, PDL2 is expressed in various types of tumors $(14,15)$. Previous research on the association between PD-L2 and RCC, triple-negative breast cancer, and esophageal adenocarcinoma has proven that PD-L2, as a crucial potential target, may also play a similarly dominant role as PD-L1 in tumor immunotherapy (16-18). Indeed, after achieving a greater understanding of tumor immunobiology, the next major challenge for researchers lies in clarifying the resistance of the PD-1/PD-L1 blockade and reaching a more substantive comprehension of PD-L2 (19).

Overall, using the prior knowledge in this field, we performed a novel meta-analysis to evaluate the prognostic significance of both PD-L1 and PD-L2 in RCC with the aim of providing a comprehensive summary based on the available evidence.

\section{Methods}

\section{Data sources and search strategy}

Before the literature search, a detailed inclusion criterion was made following the established reporting guidelines $(20,21)$. We independently and systematically searched the PubMed, Cochrane Library, and EMBASE database in October 2019, with the language of publication, restricted to English. Observational studies that assessed the effect of PD-L1 or PD-L2 on renal cell carcinoma patients and relevant clinical and pathological characteristics were included. References and citations of retrieved articles were all searched and checked carefully. To ensure reliability, the search process was performed by 3 authors using the following search terms: (programmed cell death 1 ligand 2 OR PD-L2 OR B7-DC OR CD273 OR programmed cell death ligand 1 OR PD-L1 OR B7-H1 OR CD274 OR B7 homolog 1) AND (cancer OR neoplasm OR malignancy OR carcinoma OR tumor) AND (survival OR outcome OR prognosis OR prognostic) AND (renal OR kidney). The agreement in the search process was reached through discussion. The protocol of the study was registered in PROSPERO (CRD42019135199).

\section{Inclusion and exclusion criteria}

Studies were considered to be eligible if they met the following criteria: (I) studies were original articles; (II) studies were published in English; (III) studies analyzed the relationship between PD-L1 or PD-L2 and overall survival (OS), disease-free survival (DFS), and progressionfree survival (PFS), or clinicopathological characteristics in any type of renal cell carcinoma patients; (IV) hazard ratios (HRs) and their 95\% confidence intervals (95\% CIs) for survival analysis were reported directly or could be derived from the given data. Studies failing to conform to the inclusion criteria above were excluded. If the same sample population was included in different studies, only the most recent analysis was included.

\section{Data collection}

The 3 authors independently read and screened the retrieved titles and abstracts. The details retrieved from each study included the first author, publication year, study design, country, patient demographics, histology of cancer, cutoff value, positive rate of PD-L1 and PD-L2, followup time, and survival outcomes. Any missing or unclear 


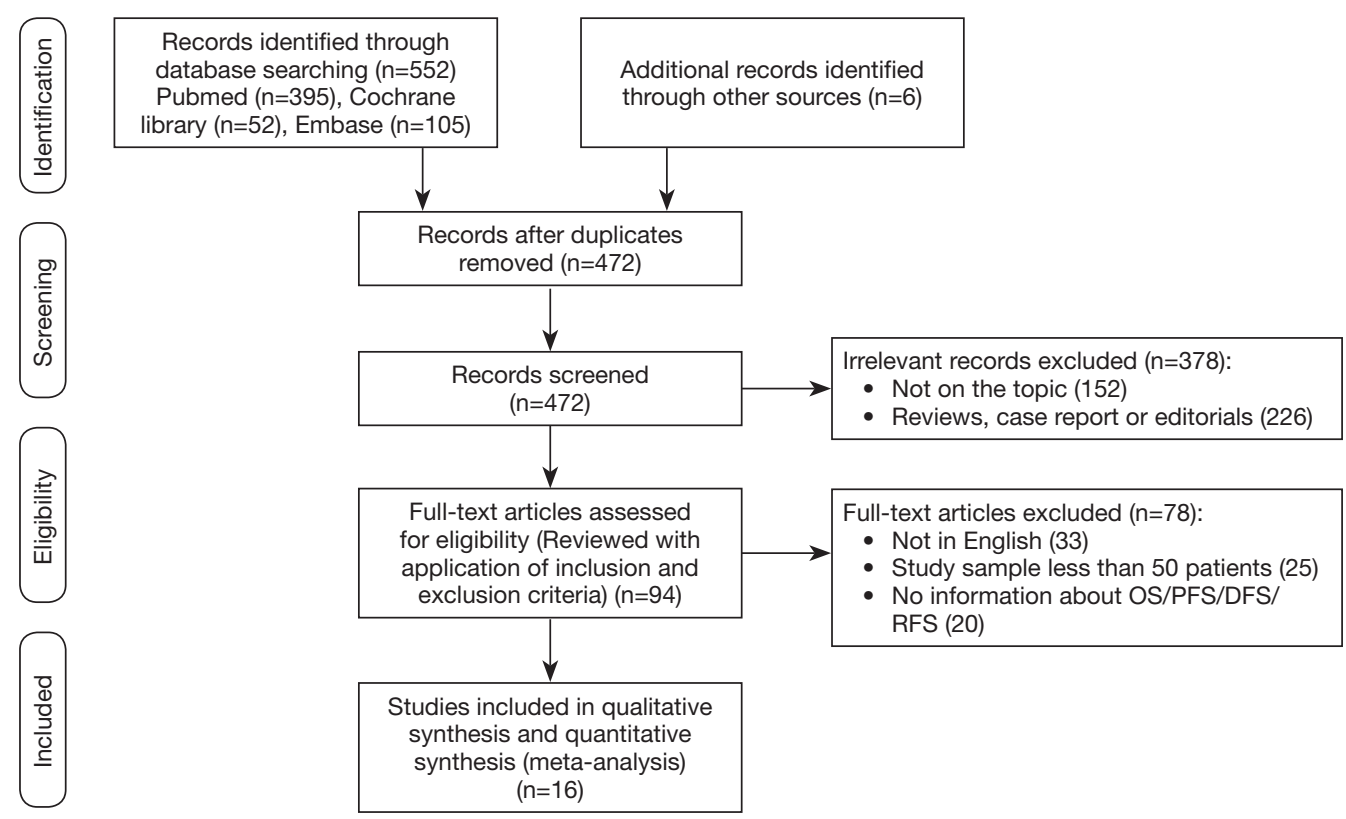

Figure 1 PRISMA flow chart of the data search. OS, overall survival; PFS, progression-free survival; DFS, disease-free survival; RFS, relapse-free survival.

information was obtained by contacting the article authors. Information was defined as not reported if the authors did not reply. For articles that only provided survival data in a Kaplan-Meier curve, we used tools designed by Tierney and Sydes (22) to digitize and extract the HR and its 95\% CI.

\section{Risk of bias (RoB) assessment}

Each of the 3 authors assessed the RoB of each included study independently. Any disagreements were resolved by consensus and communication among the 3 and with article authors. RoB of observational studies was assessed by using a modified Newcastle-Ottawa scale (NOS) (23). The scores of studies were graded from 0 to 9 according to the NOS scale for a cohort study.

\section{Statistical analysis}

The correlations between PD-L1/2 expression and the clinicopathological features of RCC (gender, invasion depth, grade, distant metastasis, lymph metastasis, vascular invasion, tumor necrosis, sarcomatoid features) were assessed by OR and $95 \%$ CIs. Hazard ratio (HR) with a 95\% CI was pooled to reveal the correlation between PDL1/2 expression and prognosis. The incidence of PD-L1/2 expression was also pooled. According to the DerSimonian and Laird method (24), random-effect models were used when we found significant heterogeneity $(\mathrm{P}<0.05$ in Cochrane Q-test) and $\mathrm{I}^{2}>50 \%$. Otherwise, fixed-effect models were used for calculations. We conducted Begg's test and created funnel plots to assess the publication bias and small-study effects. Statistical analyses were performed using RevMan 5.3 (The Cochrane Centre) and STATA 12.0 (Stata-Corp.). The significance level was set as a two-tailed $P$ value $<0.05$ in all data analyses.

\section{Results}

\section{Literature search}

By searching the electronic databases (PubMed, Embase, and the Cochrane Library) with the search strategy mentioned above and reviewing the reference lists of the retrieved studies, we identified 558 records after removing 86 duplicated records. Another 378 records were excluded because they were case reports, reviews, editorials, or not relevant topics. In the remaining 94 records, 78 of records were excluded because they were study samples, not published in English, or did not have sufficient information for OS, PFS, DFS, or relapse-free survival (RFS) calculation. After screening for the form of data reporting, 16 retrospective cohort studies (3,389 patients) (25-40) were pooled in the final meta-analysis (shown in Figure 1). 


\section{Characteristics of included studies}

The main features of the 16 studies are presented in Table 1. We included 3,389 patients in the study and all 16 studies in the review were retrospective studies. The publication dates ranged from 2004 to 2019, with 3 studies being published between 2004 and 2007 and the others being published between 2014 to 2019. According to the articles, all patients received resection. These studies were conducted across 7 countries, with 4 in Germany, 1 in China, 3 in Korea, 4 in the USA, and 1 in each of Brazil, Japan, and France. For histological type, 9 studies examined ccRCC, 1 study reported both ccRCC and non-ccRCC, and 5 studies reported nonRCC ( 2 reported chRCC and 1 reported pRCC; 2 studies did not report the exact type, just non-ccRCC). The mean follow-up time varied from 10 to 134.4 months. All the studies detected PD-L1/2 expression in tumor tissue using immunohistochemistry (IHC), and the cut-off values of high PD-L1/2 expression varied greatly across different studies, but $\geq 5 \%$ was the most common criterion. None of the patients received any type of treatment, such as chemotherapy, radiotherapy, and neoadjuvant radiotherapy before surgery. The prognostic value of PD-L1/2 for OS was mentioned in 8 studies. The correlation between PD-L1/2 expression and PFS or cancer-specific survival (CSS) was reported in 10 studies, respectively. Eight studies reported HRs adjusted for PD-L1/2 expression, and 8 studies did not make adjustments. All the studies had NOS grades $\geq 5$, which showed that all the studies were designed with high methodological quality (Table 2).

\section{Prevalence of PD-L1/2 expression in RCC}

The prevalence of PD-L1 and PD-L2 expression among RCC patients in the eligible studies ranged from $6.0-70.4 \%$ and 22.4-66.2\%, respectively (Table 1).

The pooled analysis results gave an overall prevalence of PD-L1 of $27 \%$ (random effect, 95\% CI: 0.20 to 0.34 , $\left.\mathrm{I}^{2}=96.7 \%\right)$ and an overall prevalence of PD-L2 of $39 \%$ (random effect, $95 \%$ CI: 0.24 to $0.55, \mathrm{I}^{2}=95.2 \%$ ) (Figure 2).

\section{Prognostic value of PD-L1/2 for OS, PFS, and CSS}

Survival outcomes, including OS, PFS, and CSS, were pooled and synthesized according to the PD-L type (summarized in Table 3).

Eight studies, with 1631 individuals, reported OS. Six of them revealed a correlation between PD-L1 expression and
OS. We found that PD-L1 over-expression was a strong negative predictor for OS in renal cell carcinoma patients (HR $=2.86,95 \%$ CI: 1.83-4.47, $\mathrm{P}<0.001)$. Two studies reported a correlation between PD-L2 expression and OS. Our study revealed that high PD-L2 expression had no predictive role for OS in renal cell carcinoma patients (HR =1.86, 95\% CI: 0.55-6.27, $\mathrm{P}=0.315$ ) (Figure 3).

The impact of PD-L1/2 on PFS was mentioned in 10 studies comprising 2069 patients. The forest plot (Figure 4) showed that higher PD-L1 expression was significantly associated with poor PFS (HR =2.64, 95\% CI: 1.99-3.52, $\mathrm{P}<0.001)$, while no significant association was observed between PD-L2 over-expression and PFS (HR =1.46, 95\% CI: 0.91-2.34, $\mathrm{P}=0.120$ ).

Ten studies comprising 1886 cases evaluated the impact of PD-L1/2 on CSS. The forest plot (Figure 5) showed that higher PD-L1 expression was significantly associated with poor CSS (HR =2.78, 95\% CI: $2.17-3.56, \mathrm{P}<0.001)$. We also found that PD-L2 overexpression was a weak negative predictor for CSS among renal cell carcinoma patients (HR $=1.66,95 \%$ CI: $1.05-2.65, \mathrm{P}<0.05$ ).

\section{Subgroup analysis}

Table 4 summarizes the results of subgroup analyses between PD-L1 expression and survival outcomes according to the histology of cancer, year of publication, ethnicity, and NOS score. Synthetic analysis showed that mccRCC was associated with worse PFS (HR $=2.69,95 \%$ CI: 2.03-3.56, $\mathrm{P}<0.001, \mathrm{I}^{2}=38.2 \%$ ) and CSS (HR $=2.86,95 \%$ CI: $2.20-$ $\left.3.72, \mathrm{P}<0.001, \mathrm{I}^{2}=48.9 \%\right)$ than nccRCC. Subgroup analysis by ethnicity revealed that Caucasians had worse OS (HR $=3.60,95 \%$ CI: $1.77-7.33, \mathrm{P}<0.001, \mathrm{I}^{2}=29.8 \%$ ), PFS (HR $=3.56,95 \%$ CI: $2.44-5.18, \mathrm{P}<0.001, \mathrm{I}^{2}=0.0 \%$ ), and CSS (HR $=3.13$, 95\% CI: $\left.2.37-4.14, \mathrm{P}<0.001, \mathrm{I}^{2}=0.0 \%\right)$. Subgroup analysis stratified by NOS score showed a worse OS (HR $=5.97,95 \%$ CI: $2.46-14.47, \mathrm{P}<0.001, \mathrm{I}^{2}=0.0 \%$ ), PFS (HR $=2.71,95 \%$ CI: $\left.1.91-3.83, \mathrm{P}<0.001, \mathrm{I}^{2}=0.0 \%\right)$ and CSS (HR $=2.93,95 \%$ CI: $2.18-3.95, \mathrm{P}<0.001, \mathrm{I}^{2}=49.2 \%$ ) in studies with an NOS score of 6 . Due to the small number of studies reporting the association between PD-L2 and prognostic outcomes, no further analysis was conducted although some of them showed significant heterogeneity.

\section{Association between PD-L1/2 expression and clinicopathological of RCC}

We comprehensively assessed the role of PD-L1 and PD- 


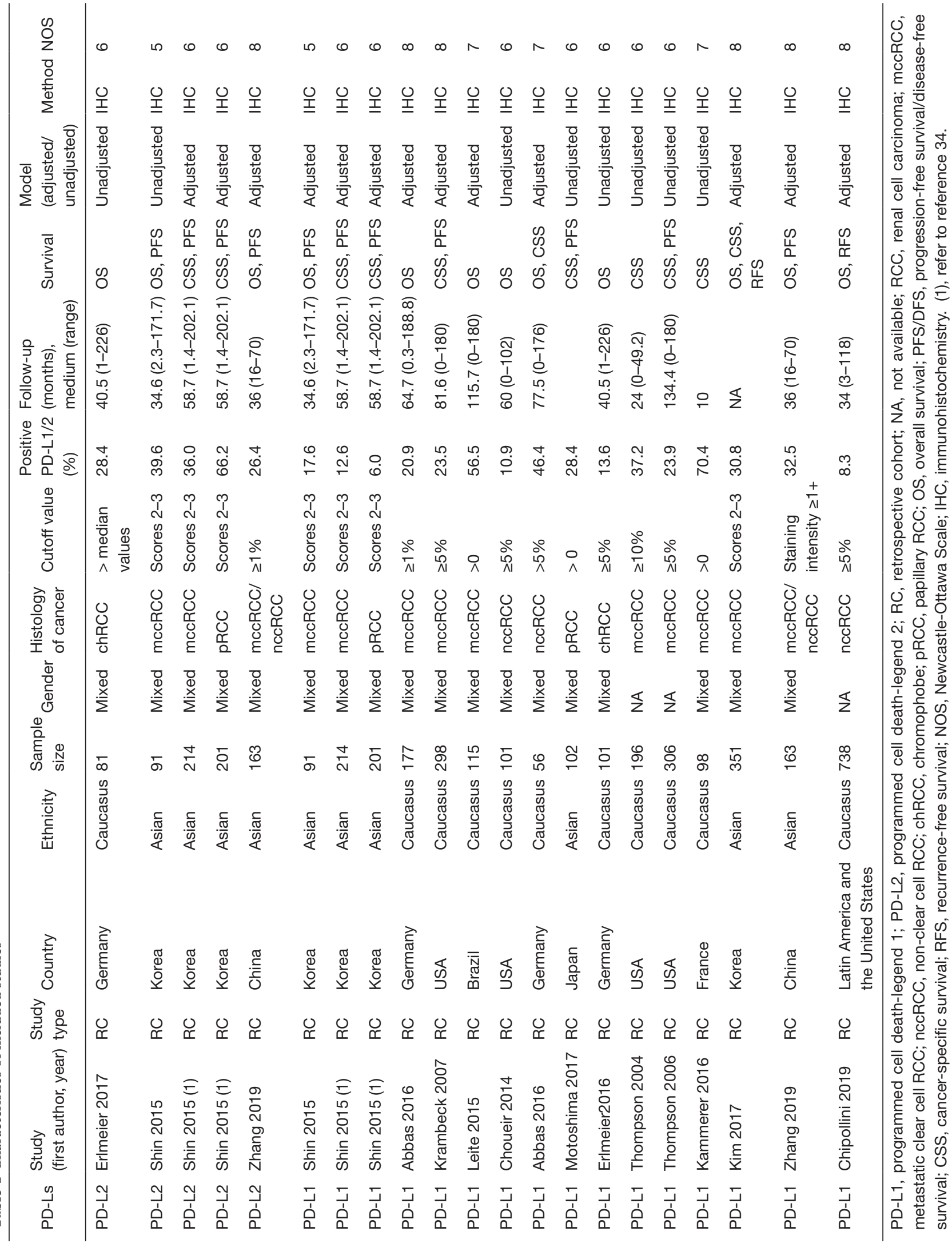




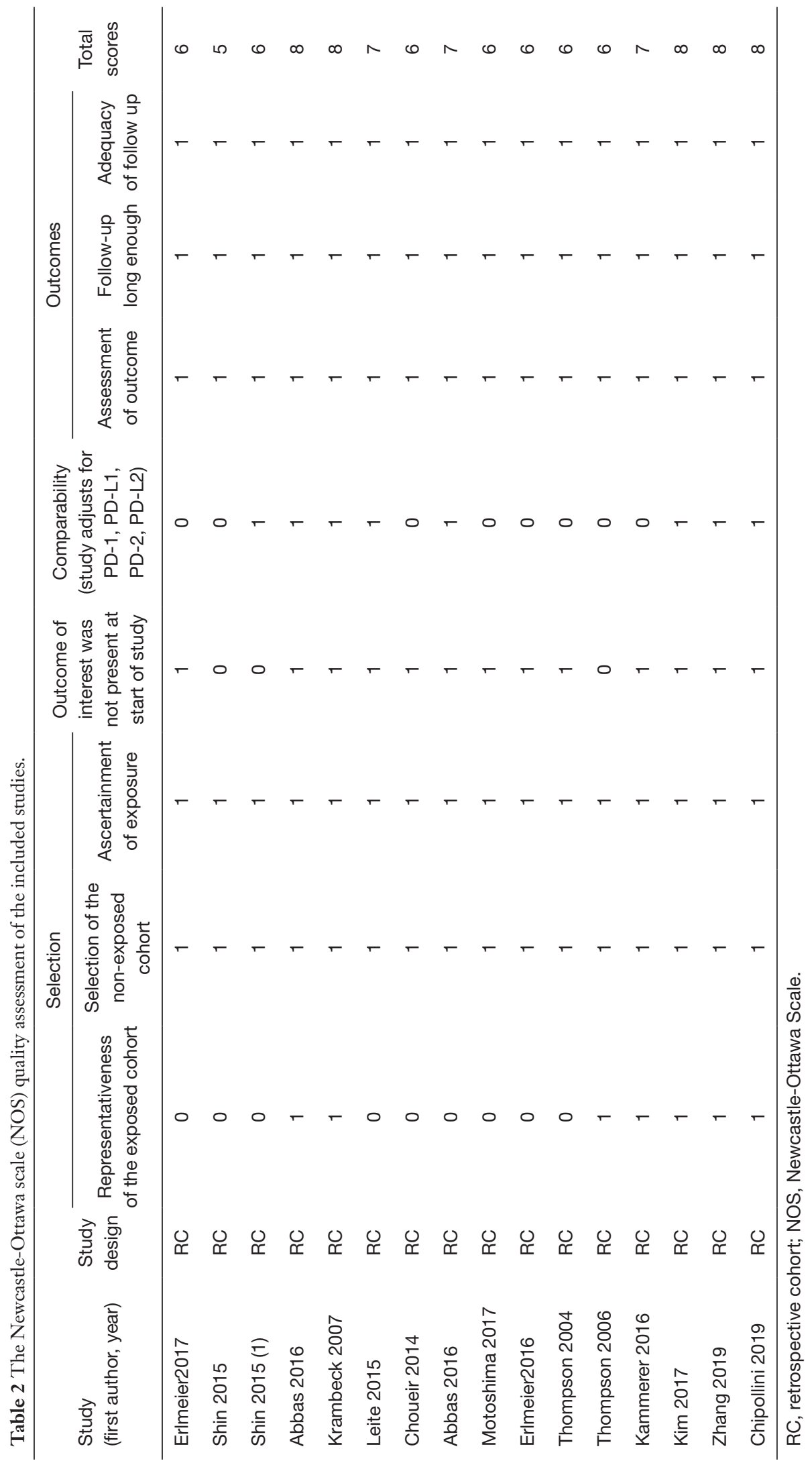




\begin{tabular}{|c|c|c|c|}
\hline \multirow{2}{*}{\multicolumn{2}{|c|}{$\begin{array}{l}\text { Study } \\
\text { ID }\end{array}$}} & \multirow[b]{2}{*}{ Prevalence $(95 \% \mathrm{Cl})$} & \multirow{2}{*}{$\begin{array}{l}\% \\
\text { Weight }\end{array}$} \\
\hline & & & \\
\hline PD-L2 & $i$ & & \\
\hline Erlmeier (2017) & & $0.28(0.19,0.38)$ & 4.58 \\
\hline Shin (2015) & - & $0.40(0.30,0.50)$ & 4.56 \\
\hline Shin (1) (2015) & - & $0.66(0.60,0.73)$ & 4.81 \\
\hline Shin (1) (2015) & $\frac{1}{1-\infty}$ & $0.36(0.30,0.42)$ & 4.81 \\
\hline Zhang (2019) & $\rightarrow$ & $0.26(0.20,0.33)$ & 4.79 \\
\hline Subtotal $(I-$ squared $=95.2 \%, p=0.000)$ & & $0.39(0.24,0.55)$ & 23.54 \\
\hline . & 1 & & \\
\hline PD-L1 & ! & & \\
\hline Shin (2015) & $\rightarrow-i$ & $0.18(0.10,0.25)$ & 4.72 \\
\hline Shin (1) (2015) & $\approx \quad 1$ & $0.13(0.08,0.17)$ & 4.91 \\
\hline Shin (1) (2015) & $\approx$ & $0.06(0.03,0.09)$ & 4.95 \\
\hline Abbas (2016) & 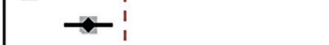 & $0.21(0.15,0.27)$ & 4.84 \\
\hline Krambeck (2007) & $\approx$ & $0.23(0.19,0.28)$ & 4.89 \\
\hline Leite (2015) & $\rightarrow$ & $0.57(0.47,0.66)$ & 4.64 \\
\hline Choueir (2014) & $\approx$ & $0.11(0.05,0.17)$ & 4.83 \\
\hline Abbas (2016) & *- & $0.46(0.33,0.59)$ & 4.29 \\
\hline Motoshima (2017) & - & $0.28(0.20,0.37)$ & 4.66 \\
\hline Erlmeier (2016) & $\rightarrow$ & $0.14(0.06,0.21)$ & 4.75 \\
\hline Thompson (2004) & $1-$ & $0.37(0.30,0.44)$ & 4.79 \\
\hline Thompson (2006) & $\rightarrow$ & $0.24(0.19,0.29)$ & 4.90 \\
\hline Kammerer (2016) & $\longrightarrow$ & $0.70(0.61,0.79)$ & 4.64 \\
\hline $\operatorname{Kim}(2017)$ & $\rightarrow$ & $0.31(0.26,0.36)$ & 4.89 \\
\hline Zhang (2019) & $\frac{1}{-1}$ & $0.33(0.25,0.40)$ & 4.77 \\
\hline Chipollini (2019) & 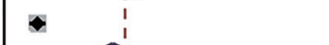 & $0.08(0.06,0.10)$ & 4.99 \\
\hline Subtotal $(I-$ squared $=96.7 \%, p=0.000)$ & & $0.27(0.20,0.34)$ & 76.46 \\
\hline & & & \\
\hline Overall (l-squared $=97.2 \%, p=0.000)$ & & $0.30(0.23,0.37)$ & 100.00 \\
\hline NOTE: Weights are from random effects analysis & & & \\
\hline $\begin{array}{c}1 \\
-0.794\end{array}$ & & & \\
\hline
\end{tabular}

Figure 2 Prevalence of PD-L1 and PD-L2 expression in RCC. PD-L1, programmed cell death-legend 1; PD-L2, programmed cell deathlegend 2; RCC, renal cell carcinoma

Table 3 Survival outcomes pooled by PD-Ls type

\begin{tabular}{|c|c|c|c|c|c|c|c|c|c|c|c|c|c|c|c|}
\hline \multirow{2}{*}{ PD-Ls } & \multicolumn{5}{|c|}{ OS } & \multicolumn{5}{|c|}{ PFS } & \multicolumn{5}{|c|}{ CSS } \\
\hline & $\begin{array}{l}\text { No. of } \\
\text { studies }\end{array}$ & $\begin{array}{c}\text { Pooled HR } \\
(95 \% \mathrm{Cl})\end{array}$ & $P$ value & $\mathrm{I}^{2}(\%)$ & $P$ value & $\begin{array}{l}\text { No. of } \\
\text { studies }\end{array}$ & $\begin{array}{c}\text { Pooled HR } \\
(95 \% \mathrm{Cl})\end{array}$ & $P$ value & $I^{2}(\%)$ & $P$ value & $\begin{array}{l}\text { No. of } \\
\text { studies }\end{array}$ & $\begin{array}{c}\text { Pooled HR } \\
(95 \% \mathrm{Cl})\end{array}$ & $\mathrm{P}$ value & $\mathrm{I}^{2}(\%)$ & $P$ value \\
\hline PD-L1 & 6 & $\begin{array}{c}2.86 \\
(1.83,4.47)\end{array}$ & 0.000 & 48.8 & 0.082 & 7 & $\begin{array}{c}2.64 \\
(1.99,3.52)\end{array}$ & 0.000 & 10.6 & 0.349 & 8 & $\begin{array}{c}2.78 \\
(2.17,3.56)\end{array}$ & 0.000 & 29.6 & 0.192 \\
\hline Total & 8 & $\begin{array}{c}2.54 \\
(1.60,4.05)\end{array}$ & 0.001 & 65.7 & 0.005 & 10 & $\begin{array}{c}2.10 \\
(1.53,2.87)\end{array}$ & 0.000 & 52.5 & 0.028 & 10 & $\begin{array}{c}2.48 \\
(2.17,3.56)\end{array}$ & 0.000 & 35.1 & 0.127 \\
\hline
\end{tabular}

PD-L1, programmed cell death-legend 1; PD-L2, programmed cell death-legend 2; OS, overall survival; PFS/DFS, progression-free survival/disease-free survival; CSS, cancer-specific survival; HR, hazard ratio; $\mathrm{Cl}$, confidence intervals. 


Study
ID

Figure 3 Prognostic value of PD-L1 and PD-L2 for OS. PD-L1, programmed cell death-legend 1; PD-L2, programmed cell death-legend 2.

Study
ID

Figure 4 Prognostic value of PD-L1 and PD-L2 for PFS/DFS. PD-L1, programmed cell death-legend 1; PD-L2, programmed cell deathlegend 2; PFS/DFS, progression-free survival/disease-free survival. 


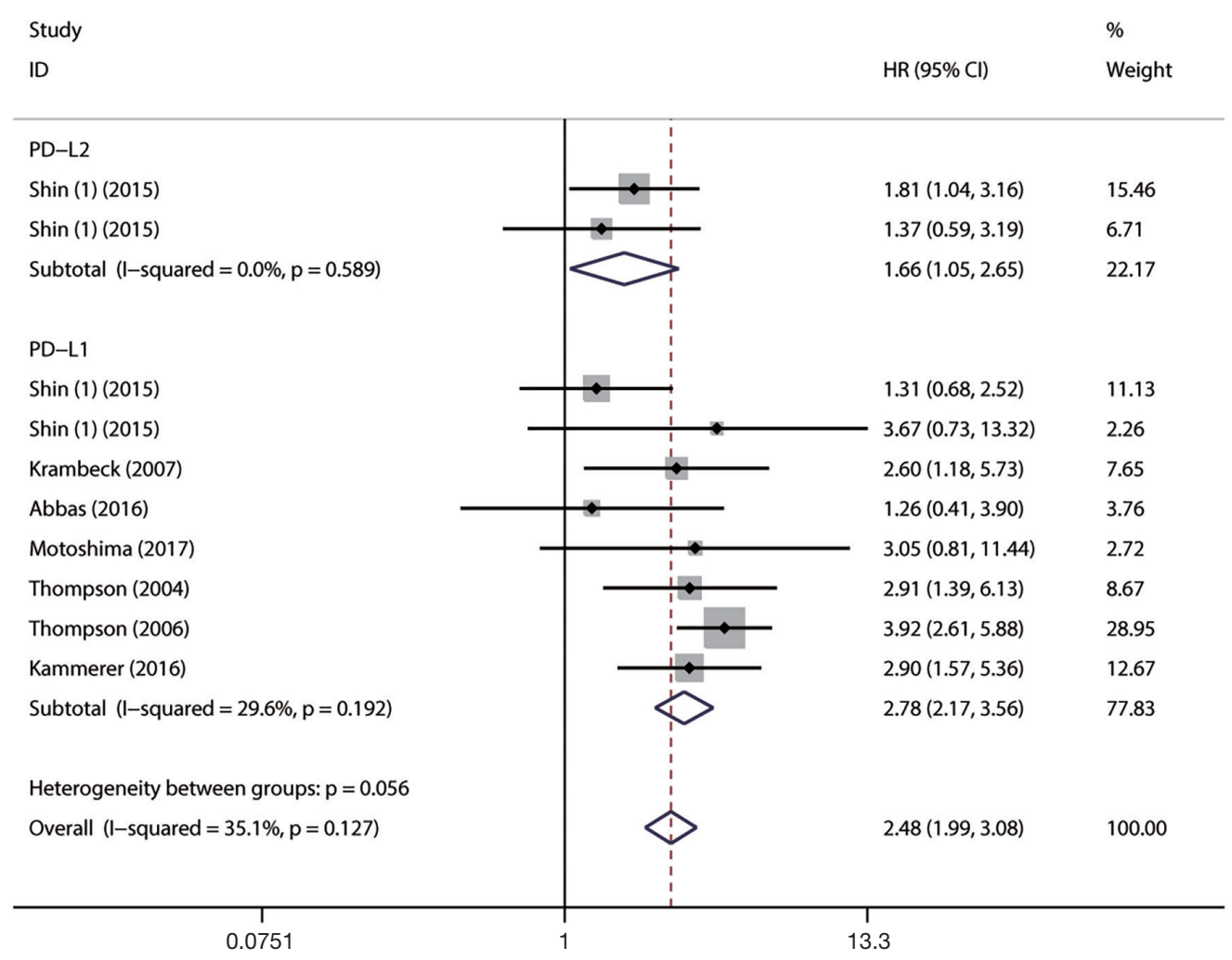

Figure 5 Prognostic value of PD-L1 and PD-L2 for CSS. PD-L1, programmed cell death-legend 1; PD-L2, programmed cell death-legend 2; CSS, cancer-specific survival.

L2 as a biochemical marker in renal cell carcinoma by studying the correlation between PD-L1/2 expression and the clinicopathology of RCC (presented in Table 5 and Figures S1-S8). A total of 15 studies including 3,389 individuals were pooled in the correlation analysis. From the results, we found that PD-L1 was a strong indicator for worse prognosis: lymphatic metastasis (presence $v s$. absence, OR $=1.9895 \% \mathrm{CI}: 1.36-2.89, \mathrm{P}=0.004)$, depth of invasion (TIII + TIV vs. TI + TII, OR $=2.52,95 \%$ CI: 1.56-4.08, $\mathrm{P}=0.013)$, histopathological stage (III + IV vs. $\mathrm{I}+\mathrm{II}, \mathrm{OR}=2.83,95 \% \mathrm{CI}: 1.76-4.54, \mathrm{P}=0.007)$, tumor metastasis (presence $v$ s. absence, OR $=2.67,95 \%$ CI: $1.73-$ 4.12, $\mathrm{P}=0.000$ ), vascular invasion (presence $v$ s. absence, $\mathrm{OR}$ $=1.65,95 \%$ CI: $1.07-2.56, \mathrm{P}=0.024$ ), necrosis (presence vs. absence, $\mathrm{OR}=3.09,95 \% \mathrm{CI}: 1.78-5.36, \mathrm{P}=0.000)$, sarcomatoid feature (presence $v s$. absence, $\mathrm{OR}=5.59,95 \%$ CI: 3.37-9.25, P=0.000). Notably, we found that PD-L1 overexpression was more prevalent in women (male $v$ s. female, $\mathrm{OR}=0.68,95 \%$ CI: 0.51-0.90, $\mathrm{P}=0.006$ ). It seemed that PD-L2 was not associated with these items, except for sarcomatoid features (presence $v$ s. absence, OR $=1.80,95 \%$ CI: $1.13-2.86, \mathrm{P}=0.014)$.

\section{Publication bias}

Begg's funnel plot and Egger's test were conducted to analyze the publication bias. No significant publication bias was found (OS: Begg's test, $\mathrm{P}=0.824$; Egger's test, $\mathrm{P}=0.558$ (Figure 6A); PFS: Begg's test, $\mathrm{P}=0.548$; Egger's test, $\mathrm{P}=0.310$ (Figure $6 \mathrm{~B}$ ); CSS: Begg's test, $\mathrm{P}=0.858$; Egger's test, $\mathrm{P}=0.331$ (Figure $6 C$ ).

\section{Sensitivity analysis}

We conducted a sensitivity analysis to evaluate the effects of a single study on the pooled results. We deleted each included study in each analysis to see whether the individual data might influence the pooled results. The results showed that the pooled results were not significantly affected by a single individual, suggesting that the combined results of the meta-analysis were reliable (Figure 7). 
Table 4 Subgroup analyses between PD-L1 expression and survival outcomes

\begin{tabular}{|c|c|c|c|c|c|c|c|c|c|c|c|c|c|c|c|}
\hline \multirow{2}{*}{$\begin{array}{l}\text { Subgroup } \\
\text { analysis }\end{array}$} & \multicolumn{5}{|c|}{ os } & \multicolumn{5}{|c|}{ PFS } & \multicolumn{5}{|c|}{ css } \\
\hline & $\begin{array}{l}\text { No. of } \\
\text { studies }\end{array}$ & $\begin{array}{c}\text { Pooled } \\
\text { HR } \\
(95 \% \mathrm{Cl})\end{array}$ & $\begin{array}{c}\mathrm{P} \\
\text { value }\end{array}$ & $\mathrm{I}^{2}(\%)$ & $P$ value & $\begin{array}{l}\text { No. of } \\
\text { studies }\end{array}$ & $\begin{array}{c}\text { Pooled } \\
\text { HR } \\
(95 \% \mathrm{Cl})\end{array}$ & $\begin{array}{c}\mathrm{P} \\
\text { value }\end{array}$ & $\mathrm{I}^{2}(\%)$ & $P$ value & $\begin{array}{l}\text { No. of } \\
\text { studies }\end{array}$ & $\begin{array}{c}\text { Pooled } \\
\text { HR } \\
(95 \% \mathrm{Cl})\end{array}$ & $\begin{array}{c}\mathrm{P} \\
\text { value }\end{array}$ & $\mathrm{I}^{2}(\%)$ & $P$ value \\
\hline Overall & 6 & $\begin{array}{c}2.86 \\
(1.83,4.47)\end{array}$ & 0.000 & 48.8 & 0.082 & 7 & $\begin{array}{c}2.64 \\
(1.99,3.52)\end{array}$ & 0.000 & 10.6 & 0.349 & 8 & $\begin{array}{c}2.78 \\
(2.17,3.56)\end{array}$ & 0.000 & 29.6 & 0.192 \\
\hline mccRCC & 3 & $\begin{array}{c}2.31 \\
(1.18,4.52)\end{array}$ & 0.015 & 71.7 & 0.029 & 5 & $\begin{array}{c}2.69 \\
(2.03,3.56)\end{array}$ & 0.000 & 38.2 & 0.167 & 5 & $\begin{array}{c}2.86 \\
(2.20,3.72)\end{array}$ & 0.000 & 48.9 & 0.098 \\
\hline nccRCC & 3 & $\begin{array}{c}5.97 \\
(2.46,14.47)\end{array}$ & 0.000 & 0.0 & 0.820 & 2 & $\begin{array}{c}2.56 \\
(1.14,5.76)\end{array}$ & 0.023 & 0.0 & 0.635 & 3 & $\begin{array}{c}2.19 \\
(1.05,4.58)\end{array}$ & 0.038 & 0.0 & 0.438 \\
\hline $\begin{array}{l}2016 \text { and } \\
\text { after }\end{array}$ & 4 & $\begin{array}{c}1.99 \\
(1.02,3.89)\end{array}$ & 0.045 & 38.3 & 0.198 & 2 & $\begin{array}{c}1.56 \\
(0.78,3.10)\end{array}$ & 0.206 & 0.0 & 0.360 & 3 & $\begin{array}{c}2.48 \\
(1.51,4.09)\end{array}$ & 0.000 & 0.0 & 0.421 \\
\hline \multicolumn{16}{|l|}{ Ethnicity } \\
\hline Caucasus & 4 & $\begin{array}{c}3.60 \\
(1.77,7.33)\end{array}$ & 0.000 & 29.8 & 0.241 & 2 & $\begin{array}{c}3.56 \\
(2.44,5.18)\end{array}$ & 0.000 & 0.0 & 0.863 & 5 & $\begin{array}{c}3.13 \\
(2.37,4.14)\end{array}$ & 0.000 & 0.0 & 0.407 \\
\hline Asian & 2 & $\begin{array}{c}2.22 \\
(0.72,6.86)\end{array}$ & 0.164 & 85.0 & 0.010 & 5 & $\begin{array}{c}2.02 \\
(1.40,2.94)\end{array}$ & 0.000 & 0.0 & 0.680 & 3 & $\begin{array}{c}1.75 \\
(1.01,3.01)\end{array}$ & 0.045 & 17.6 & 0.297 \\
\hline \multicolumn{16}{|l|}{ NOS score } \\
\hline 5 & 1 & $\begin{array}{c}3.77 \\
(2.51,5.66)\end{array}$ & 0.000 & - & - & 1 & $\begin{array}{c}2.53 \\
(1.22,5.25)\end{array}$ & 0.013 & - & - & & - & - & - & - \\
\hline 8 & 3 & $\begin{array}{c}1.68 \\
(0.89,3.16)\end{array}$ & 0.108 & 31.6 & 0.227 & 2 & $\begin{array}{c}2.69 \\
(1.65,4.39)\end{array}$ & 0.000 & 76.7 & 0.038 & 1 & $\begin{array}{c}2.60 \\
(1.18,5.73)\end{array}$ & 0.018 & - & - \\
\hline
\end{tabular}

OS, overall survival; PFS/DFS, progression-free survival/disease-free survival; CSS, cancer-specific survival; HR, hazard ratio; CI, confidence intervals; -, not available.

\section{Discussion}

Recently, much attention has been paid to the advancement and progress of studies investigating the implication of PD-L1/2 in tumor immunity. However, significant disagreement still exists among these studies. PDL1, which was first introduced in 1999 by Dong and colleagues (41), is a normally expressed protein on the cell surface. The mechanisms of these critical molecules in cancer immunotherapy has been well illustrated in previous research (41-48). Furthermore, antibodies to
PD-1/PD-L1 have been approved for treating several types of malignancies, such as skin melanoma, bladder cancer, etc., representing significant progress on the road to cancer treatment (49). PD-L2, a new but seldom discussed protein, functions mainly by adjusting the $\mathrm{T}$ helper type 2 (Th2) cell response (50), and research on PD-L2 may also provide new insights into solving the drug resistance of PD-1/PD-L1 blockade (19).

Overall, this is the newest and the most comprehensive meta-analysis reporting the prevalence and prognostic and 
Table 5 Association between PD-L1/2 expression and clinicopathological of RCC

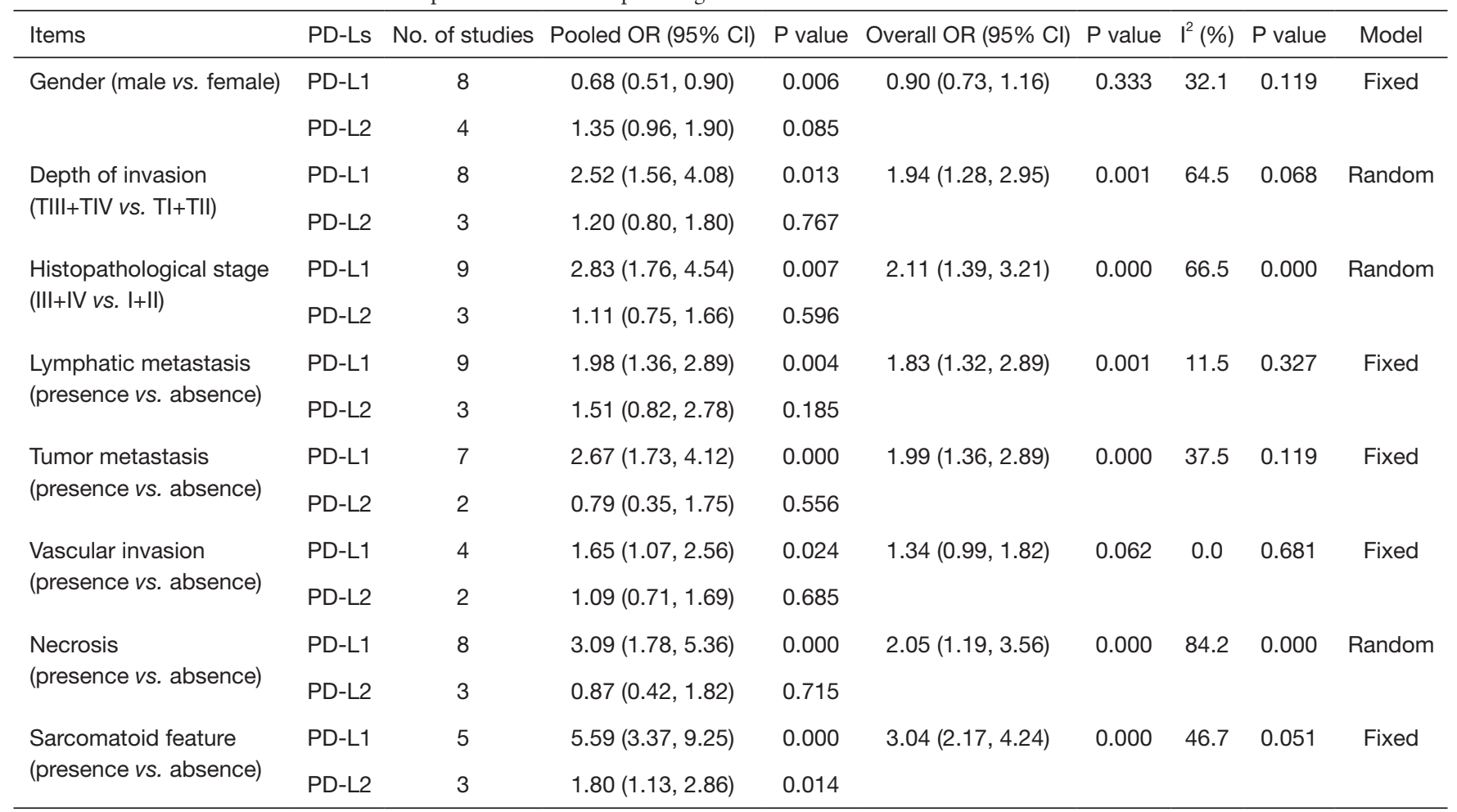

PD-L1, programmed cell death-legend 1; PD-L2, programmed cell death-legend 2; OR, odds ratio; Cl, confidence intervals; RCC, renal cell carcinoma.

clinicopathological value of PD-L1 and PD-L2 in RCC patients. A past meta-analysis had investigated the impact of PD-L1 expression alone on overall survival (OS) and the association between PD-L1 and clinicopathological features, such as tumor stage, lymph node involvement, distant metastases, nuclear grade, and histologic necrosis (51). We included 16 eligible and high-quality studies with 3,389 patients, performed further subgroup analysis, and introduced more details to the review and meta-analysis. Notably, we are the first to report a correlation between PD-L1/2 expression and gender; it is also the first time that the correlation between the over-expression of PD-L2 and survival outcomes has been evaluated and that clinically significant comparisons between PD-L1 and PD-L2 have been made.

Based on the pooled results, the prevalence of PDL1 and PD-L2 was $27 \%$ and $39 \%$, respectively. The high variations in studies for the prevalence of PD-L1/2 might be attributed to the differences of IHC techniques, including the definition of cut-off values and primary antibody species etc. Previous studies have shown that PD-
L1/2 is commonly expressed in RCC patients $(34,35)$. The pooled results might be influenced by the low number of studies reporting PD-L2 expression in RCC patients. More studies investigating PD-L1/2 expression and their relations with prognostic outcomes are thus required.

Another meta-analysis by Yang and colleagues investigated the association between PD-L2 and solid tumors, revealing that $\mathrm{PD}-\mathrm{L} 2$ over-expression predicts poor PFS in RCC patients (16). According to our pooled results, PD-L1 was a strong negative predictor for OS, DFS/PFS, and CSS in RCC patients, and PD-L2 had only a weak negative prognostic value for CSS. It seems that PD-L1 is a more powerful prognostic predictor for survival outcomes in RCC patients. These results, however, might be limited by a dearth of eligible PD-L2 studies. More research investigating the prognostic values of PD-L2 might be needed to explore this matter more extensively. Subgroup analysis revealed that the prognostic significance of PD-L1 varied according to ethnicity, histology, and other factors. PD-L1 overexpression in Caucasians showed poorer survival outcomes in OS, PFS/DFS, and CSS than in 


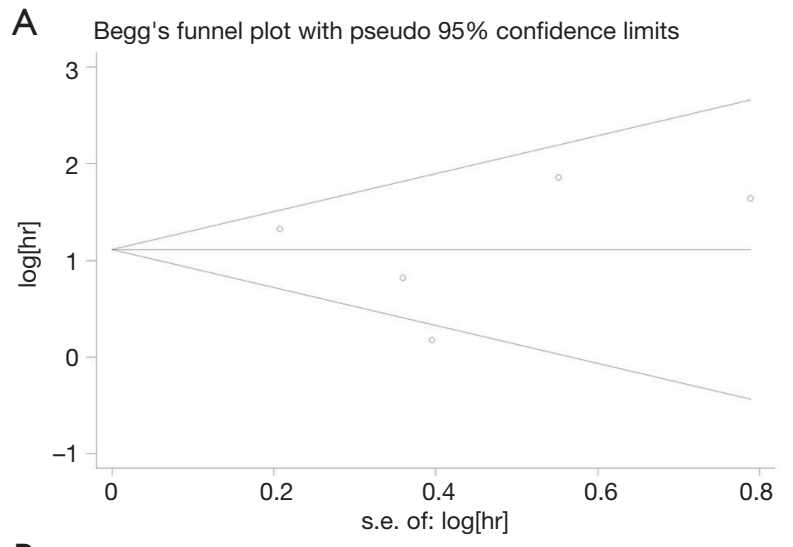

B Begg's funnel plot with pseudo $95 \%$ confidence limits
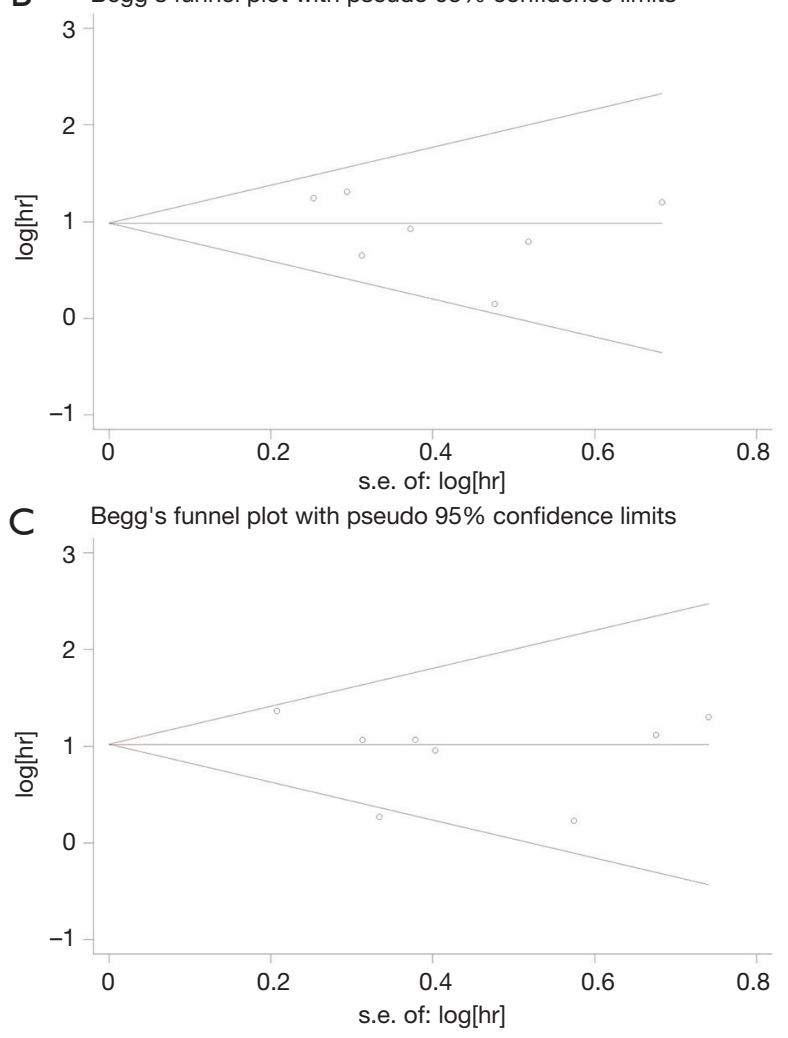

Figure 6 Funnel plots based on PD-L1 for overall survival (A), disease-free survival (B) and cancer-specific survival (C). PD-L1, programmed cell death-legend 1 .

Asians. A multi-year randomized-controlled trial conducted by Horn et al. has demonstrated that PD-1/PD-L1-related immunotherapy in treating non-small-cell lung cancer (NSCLC) provides long-term clinical benefits and favorable tolerability with no observed differences among different ethnicities (52). Thus, whether the prognostic value of PD-L1/2 in RCC patients differs across ethnic types, and

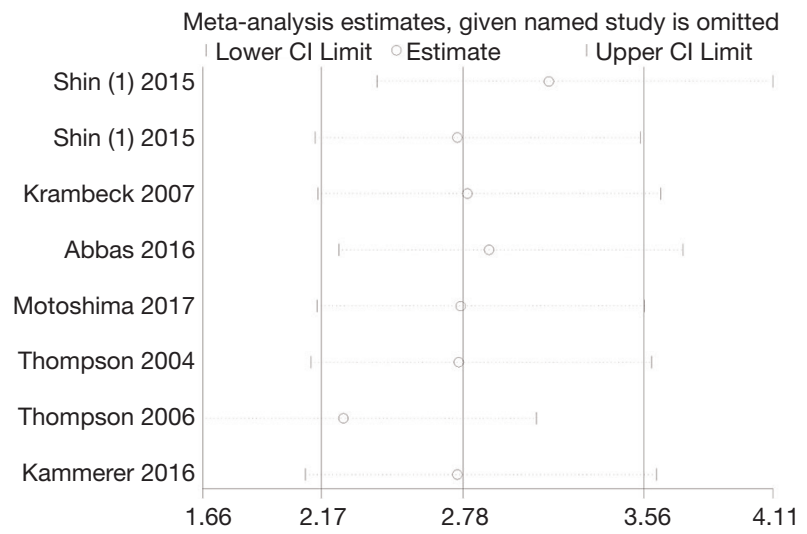

Figure 7 Sensitivity analysis (PD-L1 for disease-free survival). PD-L1, programmed cell death-legend 1.

what effects these differences might entail, remains to be discovered.

Additionally, higher PD-L1 expression implied more advanced clinicopathological features, such as depth of invasion, histopathological stage, lymphatic metastasis, tumor metastasis, vascular invasion, tumor necrosis, and sarcomatoid features; however, tumors with high PDL2 expression displayed only a weak trend of sarcomatoid features. Meng et al. found PD-L1 over-expression to be associated with poor clinical characteristics (53), which is consistent with our findings. Further investigations into the mechanisms of the PD-L2 effect in RCC immunity are required to understand the role of PD-L2. It is also worth noting that PD-L1 overexpression was more prevalent in women with RCC, which, to our knowledge, is the first time this finding has been reported. A former published article (54) emphasized that the immune treatment efficacy differences between different gender in melanoma and nonsmall-cell lung cancer. Further well-designed, large cohort studies need to be conducted in order to confirm this trend. Additionally, as was revealed in a previous study (40), PDL1 status was associated with the prognosis of kidney cancer patients which could help stratify patients for stricter surveillance.

Some limitations of this meta-analysis should be addressed. (I) IHC techniques were used extensively in these studies, and inconsistency in the definition of cutoff values and primary antibody species, etc. might have contributed to heterogeneity. A uniform standard is required to explore this issue better. (II) With the extensively heterogenous cutoff values of PD-L1/2, no further subgroup analysis according to cut-off values, was performed. (III) Finally, the 
number of eligible studies related to PD-L2 and including RCC patients was relatively small. Thus, no detailed subgroup analysis of PD-L2 could be completed. We, therefore, recommend this as an inducement to researchers to design more large-cohort clinical trials.

\section{Conclusions}

The prevalence of PD-L1 and PD-L2 expressed in RCC was $27 \%$ and $39 \%$, respectively. Higher PD-L1 expression is associated with poorer prognosis and more advanced clinicopathological features in RCC patients than PD-L2, especially in women and Caucasian patients. Furthermore, PD-L2 is a weak negative predictor of poor CSS of RCC and is not a good indicator of RCC metastasis.

\section{Acknowledgments}

Funding: This work was supported by the Zhao YiCheng Medical Science Foundation, China [grant No. ZYYFY2018031].

\section{Footnote}

Conflicts of Interest: All authors have completed the ICMJE uniform disclosure form (available at http://dx.doi. org/10.21037/tau.2020.01.21). The authors have no conflicts of interest to declare.

Ethical Statement: The authors are accountable for all aspects of the work in ensuring that questions related to the accuracy or integrity of any part of the work are appropriately investigated and resolved. All the procedures performed were in full accordance with the ethical standards of the appropriate national and institutional committees on human experimentation and with the Helsinki Declaration. Ethics approval was obtained from Tianjin Medical University General Hospital ethics committee. The need for consent to participate was waived by Ethics Commission of Tianjin Medical University General Hospital.

Open Access Statement: This is an Open Access article distributed in accordance with the Creative Commons Attribution-NonCommercial-NoDerivs 4.0 International License (CC BY-NC-ND 4.0), which permits the noncommercial replication and distribution of the article with the strict proviso that no changes or edits are made and the original work is properly cited (including links to both the formal publication through the relevant DOI and the license). See: https://creativecommons.org/licenses/by-nc-nd/4.0/.

\section{References}

1. Bray F, Ferlay J, Soerjomataram I, et al. Global cancer statistics 2018: GLOBOCAN estimates of incidence and mortality worldwide for 36 cancers in 185 countries. CA Cancer J Clin 2018;68:394-424.

2. Rini BI, Campbell SC, Escudier B. Renal Cell Carcinoma. Lancet 2009;373:1119-32.

3. Theis RP, Dolwick Grieb SM, Burr D, et al. Smoking, environmental tobacco smoke, and risk of renal cell cancer: a population-based case-control study. BMC Cancer 2008;8:387.

4. Gupta K, Miller JJ, Russell M, et al. Epidemiologic and socioeconomic burden of metastatic renal cell carcinoma (mRCC): A literature review. Cancer Treat Rev 2008;34:193-205.

5. Thomas JS, Kabbinavar F. Metastatic clear cell renal cell carcinoma: A review of current therapies and novel immunotherapies. Crit Rev Oncol Hematol 2015;96:527-33.

6. Postow MA, Callahan MK, Wolchok JD. Immune Checkpoint Blockade in Cancer Therapy. J Clin Oncol 2015;33:1974-82.

7. Dreyling M, Ghielmini M, Marcus R, et al. Newly diagnosed and relapsed follicular lymphoma: ESMO Clinical Practice Guidelines for diagnosis, treatment and follow-up. Ann Oncol 2011;22:vi59-63.

8. Bahig H, Aubin F, Stagg J, et al. Phase I/II trial of Durvalumab plus Tremelimumab and stereotactic body radiotherapy for metastatic head and neck carcinoma. BMC Cancer 2019;19:68.

9. Herzberg B, Campo MJ, Gainor JF. Immune checkpoint inhibitors in non-small cell lung cancer. Oncologist 2017;22:81-8.

10. Rittmeyer A, Barlesi F, Waterkamp D, et al. Atezolizumab versus docetaxel in patients with previously treated non-small-cell lung cancer (OAK): a phase 3, openlabel, multicentre randomised controlled trial. Lancet 2017;389:255-65.

11. Balar AV, Galsky MD, Rosenberg JE, et al. Atezolizumab as first-line treatment in cisplatin-ineligible patients with locally advanced and metastatic urothelial carcinoma: a single-arm, multicentre, phase 2 trial. Lancet 2017;389:67-76.

12. Latchman Y, Wood CR, Chernova T, et al. PD-L2 is a 
second ligand for PD-1 and inhibits T cell activation. Nat Immunol 2001;2:261.

13. Wang Q, Liu F, Liu L. Prognostic significance of PDL1 in solid tumor: an updated meta-analysis. Medicine (Baltimore) 2017;96:e6369.

14. Ahmad SM, Martinenaite E, Holmström M, et al. The inhibitory checkpoint, PD-L2, is a target for effector T cells: Novel possibilities for immune therapy. Oncoimmunology 2017;7:e1390641.

15. Panjwani PK, Charu V, DeLisser M, et al. Programmed death-1 ligands PD-L1 and PD-L2 show distinctive and restricted patterns of expression in lymphoma subtypes. Hum Pathol 2018;71:91-9.

16. Yang H, Zhou X, Sun L, et al. Correlation between PD-L2 expression and clinical outcome in solid cancer patients: a meta-analysis. Front Oncol 2019;9:47.

17. Yearley JH, Gibson C, Yu N, et al. PD-L2 expression in human tumors: relevance to anti-PD-1 therapy in cancer. Clin Cancer Res 2017;23:3158-67.

18. Derks S, Nason KS, Liao X, et al. Epithelial PD-L2 expression marks Barrett's esophagus and esophageal adenocarcinoma. Cancer Immunol Res

2015;3:1123-9.

19. Shergold AL, Millar R, Nibbs RJB. Understanding and Overcoming the Resistance of Cancer to PD-1/PD-L1 Blockade. Pharmacol Res 2019;145:104258.

20. Stroup DF, Berlin JA, Morton SC, et al. Meta-analysis of Observational Studies in EpidemiologyA Proposal for Reporting. JAMA 2000;283:2008-12.

21. Knobloch K, Yoon U, Vogt PM. Preferred reporting items for systematic reviews and meta-analyses (PRISMA) statement and publication bias. J Craniomaxillofac Surg 2011;39:91-2.

22. Tierney JF, Stewart LA, Ghersi D, et al. Practical methods for incorporating summary time-to-event data into metaanalysis. Trials. 2007;8:16.

23. Stang A. Critical evaluation of the Newcastle-Ottawa scale for the assessment of the quality of nonrandomized studies in meta-analyses. Eur J Epidemiol 2010;25:603-5.

24. DerSimonian R, Kacker R. Random-effects model for meta-analysis of clinical trials: an update. Contemp Clin Trials 2007;28:105-14.

25. Thompson RH, Kuntz SM, Leibovich BC, et al. Tumor B7-H1 Is Associated with Poor Prognosis in Renal Cell Carcinoma Patients with Long-term Follow-up. Cancer Res. 2006;66:3381-5.

26. Thompson RH, Gillett MD, Cheville JC, et al. Costimulatory B7-H1 in renal cell carcinoma patients:
Indicator of tumor aggressiveness and potential therapeutic target. Proc Natl Acad Sci U S A 2004;101:17174-9.

27. Erlmeier F, Hartmann A, Autenrieth M, et al. PD-1/PDL1 expression in chromophobe renal cell carcinoma: An immunological exception? Med Oncol 2016;33:120.

28. Motoshima T, Komohara Y, Ma C, et al. PD-L1 expression in papillary renal cell carcinoma. BMC Urol 2017;17:8.

29. Abbas M, Steffens S, Bellut M, et al. Do programmed death 1 (PD-1) and its ligand (PD-L1) play a role in patients with non-clear cell renal cell carcinoma? Med Oncol 2016;33:59.

30. Choueiri TK, Fay AP, Gray KP, et al. PD-L1 expression in nonclear-cell renal cell carcinoma. Ann Oncol 2014;25:2178-84.

31. Leite KRM, Reis ST, Junior JP, et al. PD-L1 expression in renal cell carcinoma clear cell type is related to unfavorable prognosis. Diagn Pathol 2015;10:189.

32. Krambeck AE, Dong H, Thompson RH, et al. Survivin and B7-H1 Are Collaborative Predictors of Survival and Represent Potential Therapeutic Targets for Patients with Renal Cell Carcinoma. Clin Cancer Res 2007;13:1749-56.

33. Abbas M, Steffens S, Bellut M, et al. Intratumoral expression of programmed death ligand 1 (PD-L1) in patients with clear cell renal cell carcinoma (ccRCC). Med Oncol 2016;33:80.

34. Shin SJ, Jeon YK, Kim P, et al. Clinicopathologic Analysis of PD-L1 and PD-L2 Expression in Renal Cell Carcinoma: Association with Oncogenic Proteins Status. Ann Surg Oncol 2016;23:694-702.

35. Shin SJ, Jeon YK, Cho YM, et al. The Association Between PD-L1 Expression and the Clinical Outcomes to Vascular Endothelial Growth Factor-Targeted Therapy in Patients With Metastatic Clear Cell Renal Cell Carcinoma. Oncologist 2015;20:1253-60.

36. Erlmeier F, Weichert W, Autenrieth M, et al. PD-L2: A prognostic marker in chromophobe renal cell carcinoma? Med Oncol 2017;34:71.

37. Kim SH, Park WS, Park EY, et al. The prognostic value of BAP1, PBRM1, pS6, PTEN, TGase2, PDL1, CA9, PSMA, and Ki-67 tissue markers in localized renal cell carcinoma: A retrospective study of tissue microarrays using immunohistochemistry. PLoS One 2017;12:e0179610.

38. Zhang X, Yin X, Zhang H, et al. Differential expressions of PD-1, PD-L1 and PD-L2 between primary and metastatic sites in renal cell carcinoma. BMC Cancer 2019;19:360.

39. Kammerer-Jacquet SF, Crouzet L, Brunot A, et al. Independent association of PD-L1 expression with non 
inactivated VHL clear cell renal cell carcinoma-A finding with therapeutic potential. Int J Cancer 2017;140:142-8.

40. Chipollini J, Da Costa WH, Werneck Da Cunha I, et al. Prognostic value of PD-L1 expression for surgically treated localized renal cell carcinoma: implications for risk stratification and adjuvant therapies. Ther Adv Urol 2019;11:1756287219882600.

41. Dong H, Zhu G, Tamada K, et al. B7-H1, a third member of the B7 family, co-stimulates T-cell proliferation and interleukin-10 secretion. Nat Med 1999;5:1365.

42. Zhang $\mathrm{S}$, Zhang E, Long J, et al. Immune Infiltration in Renal Cell Carcinoma. Cancer Sci 2019;110:1564-72.

43. Lecis D, Sangaletti S, Colombo MP, et al. Immune Checkpoint Ligand Reverse Signaling: Looking Back to Go Forward in Cancer Therapy. Cancers (Basel) 2019;11. doi: 10.3390/cancers11050624. .

44. Wang J, Yuan R, Song W, et al. PD-1, PD-L1 (B7-H1) and Tumor-Site Immune Modulation Therapy: The Historical Perspective. J Hematol Oncol 2017;10:34.

45. Ohaegbulam KC, Assal A, Lazar-Molnar E, et al. Human cancer immunotherapy with antibodies to the PD-1 and PD-L1 pathway. Trends Mol Med 2015;21:24-33.

46. Taube JM. Unleashing the immune system: PD-1 and PD-Ls in the pre-treatment tumor microenvironment and correlation with response to PD-1/PD-L1 blockade. Oncoimmunology 2014;3:e963413.

47. Strome SE, Haidong D, Hideto T, et al. B7-H1 blockade augments adoptive $\mathrm{T}$-cell immunotherapy for squamous

Cite this article as: $\mathrm{Lu} \mathrm{Y,} \mathrm{Song} \mathrm{Y,} \mathrm{Xu} \mathrm{Y,} \mathrm{Ou} \mathrm{N,} \mathrm{Liang} \mathrm{Z,} \mathrm{Hu}$ R, Zhang W, Kang J, Wang X, Liu L, Yang Y, Liu X. The prevalence and prognostic and clinicopathological value of $\mathrm{PD}$ L1 and PD-L2 in renal cell carcinoma patients: a systematic review and meta-analysis involving 3,389 patients. Transl Androl Urol 2020;9(2):367-381. doi: 10.21037/tau.2020.01.21 cell carcinoma. Cancer Res. 2003;63:6501-5.

48. Iwai Y, Ishida M, Tanaka Y, et al. Involvement of PD-L1 on tumor cells in the escape from host immune system and tumor immunotherapy by PD-L1 blockade. Proc Natl Acad Sci U S A 2002;99:12293-7.

49. Haffner MC, Guner G, Taheri D, et al. Comprehensive Evaluation of Programmed Death-Ligand 1 Expression in Primary and Metastatic Prostate Cancer. Am J Pathol 2018;188:1478-85.

50. Ishiwata K, Watanabe N, Guo M, et al. Costimulator B7-DC attenuates strong Th2 responses induced by Nippostrongylus brasiliensis. J Immunol 2010;184:2086-94.

51. Wang Z, Peng S, Xie H, et al. Prognostic and clinicopathological significance of PD-L1 in patients with renal cell carcinoma: a meta-analysis based on 1863 individuals. Clin Exp Med 2018;18:165-75.

52. Horn L, Spigel DR, Vokes EE, et al. Nivolumab Versus Docetaxel in Previously Treated Patients With Advanced Non-Small-Cell Lung Cancer: Two-Year Outcomes From Two Randomized, Open-Label, Phase III Trials (CheckMate 017 and CheckMate 057). J Clin Oncol 2017;35:3924-33.

53. Meng X, Huang Z, Teng F, et al. Predictive biomarkers in PD-1/PD-L1 checkpoint blockade immunotherapy. Cancer Treat Rev 2015;41:868-76.

54. Conforti F, Pala L, Bagnardi V, et al. Cancer immunotherapy efficacy and patients' sex: a systematic review and meta-analysis. Lancet Oncol 2018;19:737-46. 


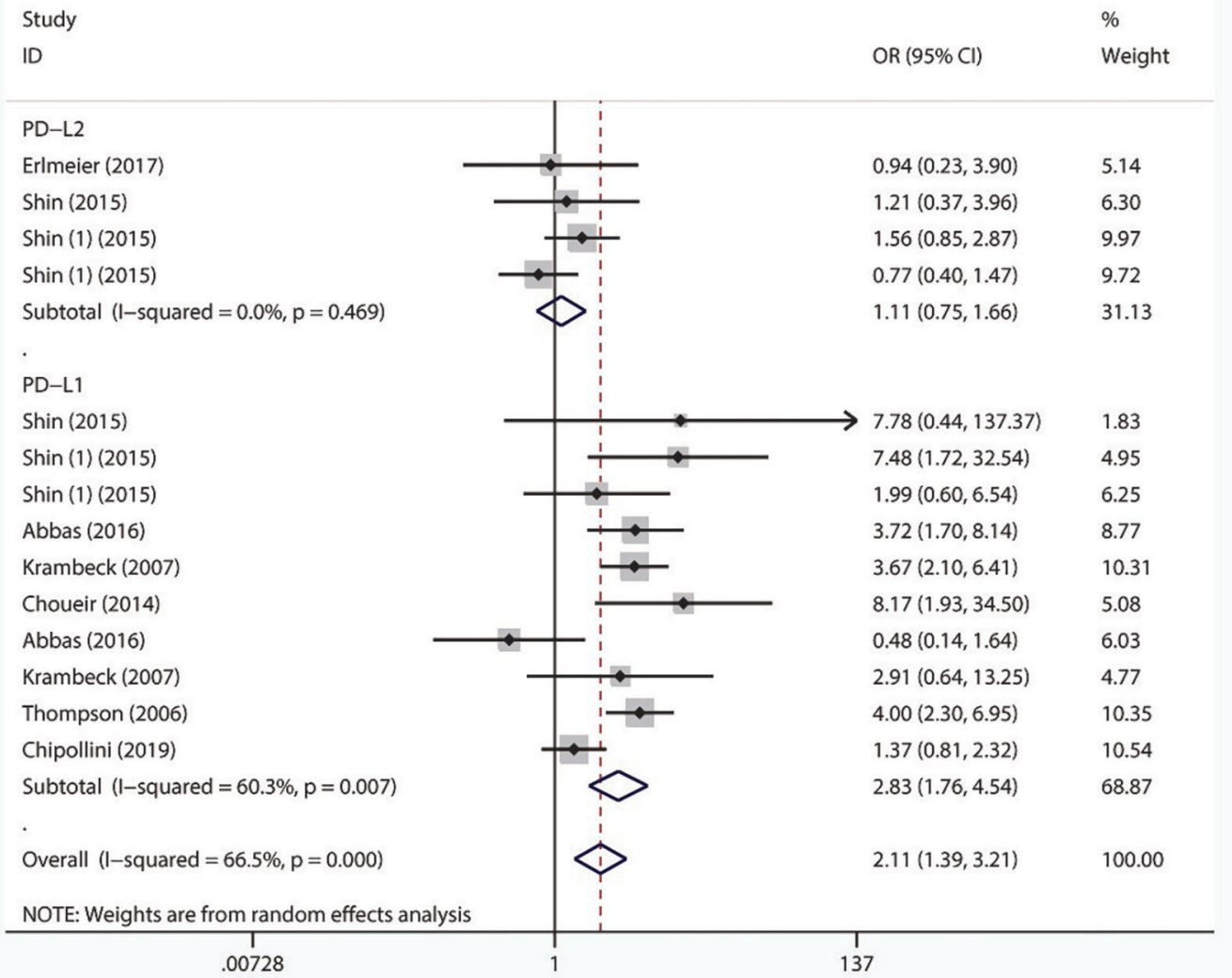

Figure S1 Correlation between PD-L1/2 expression and histopathological stage of RCC. RCC, renal cell carcinoma; PD-L1/2, programmed cell death ligand $1 / 2$.

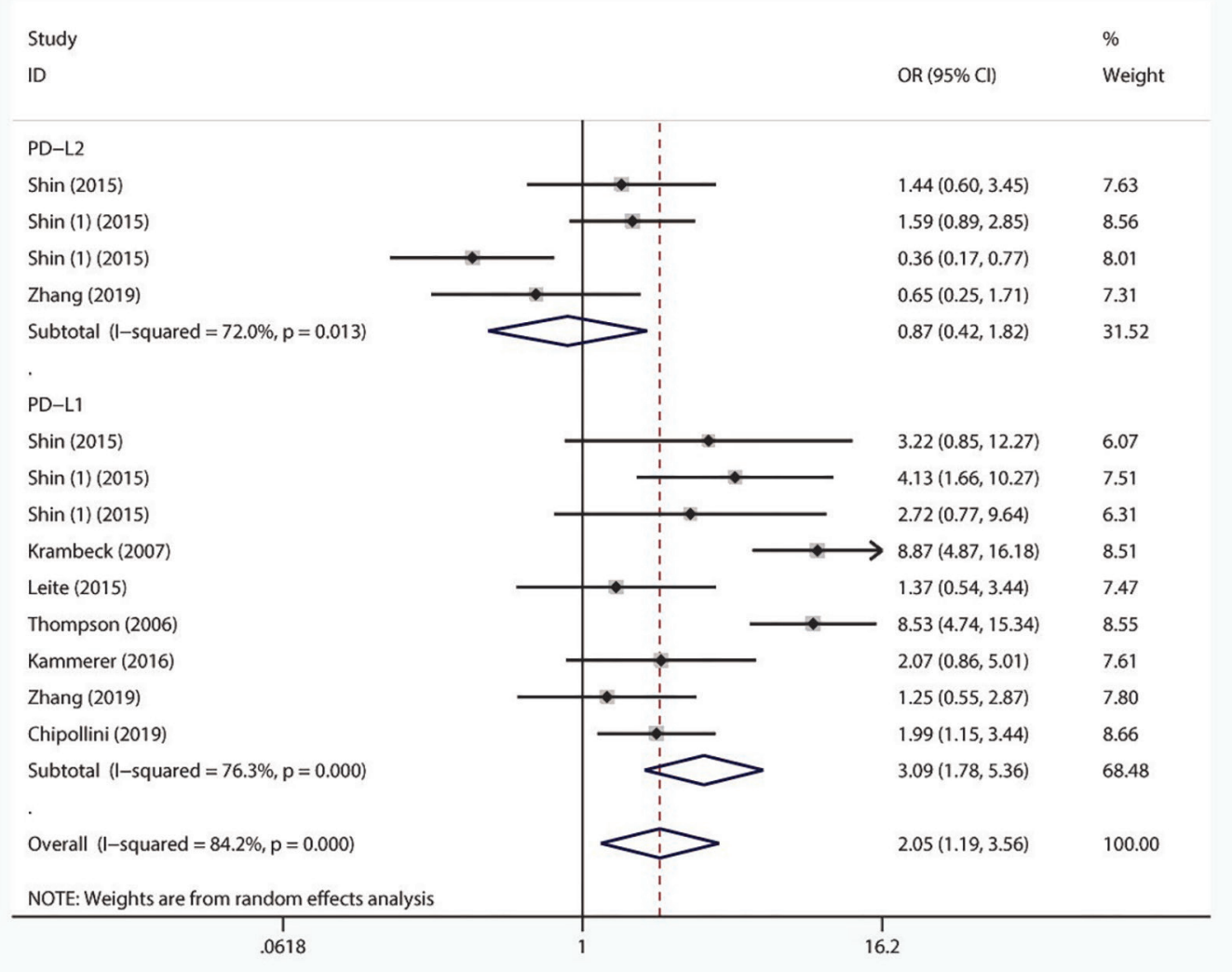

Figure S2 Correlation between PD-L1/2 expression and necrosis of RCC. RCC, renal cell carcinoma; PD-L1/2, programmed cell death ligand $1 / 2$. 


Study
ID

Figure S3 Correlation between PD-L1/2 expression and depth of invasion of RCC. RCC, renal cell carcinoma; PD-L1/2, programmed cell death ligand $1 / 2$.

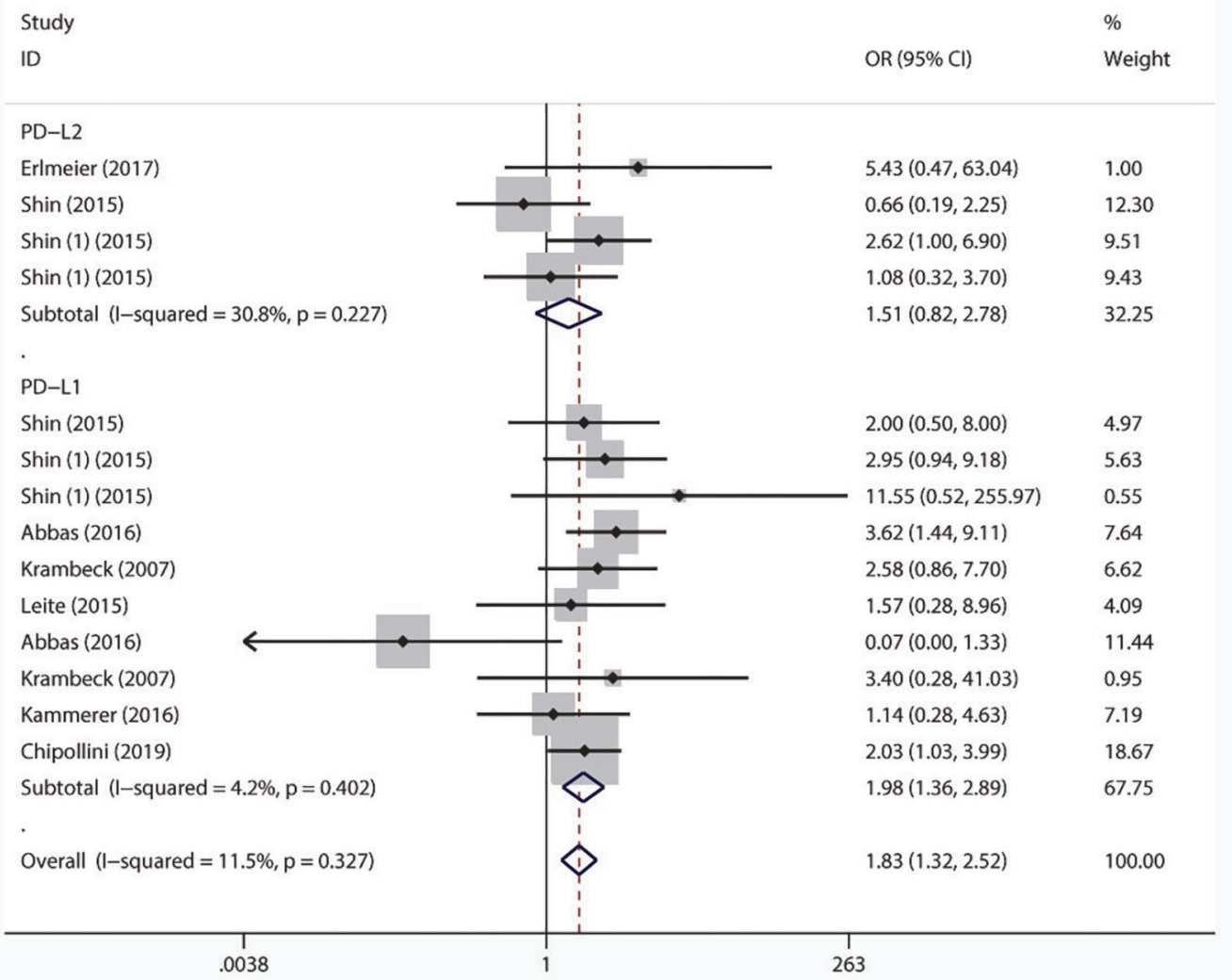

Figure S4 Correlation between PD-L1/2 expression and lymph metastasis of RCC. RCC, renal cell carcinoma; PD-L1/2, programmed cell death ligand $1 / 2$. 


$\begin{array}{llll}\text { Study } & & & \\ \text { OR (95\% Cl) } & & \\ \text { Weight }\end{array}$

Figure S5 Correlation between PD-L1/2 expression and sarcomatoid feature of RCC. RCC, renal cell carcinoma; PD-L1/2, programmed cell death ligand $1 / 2$.

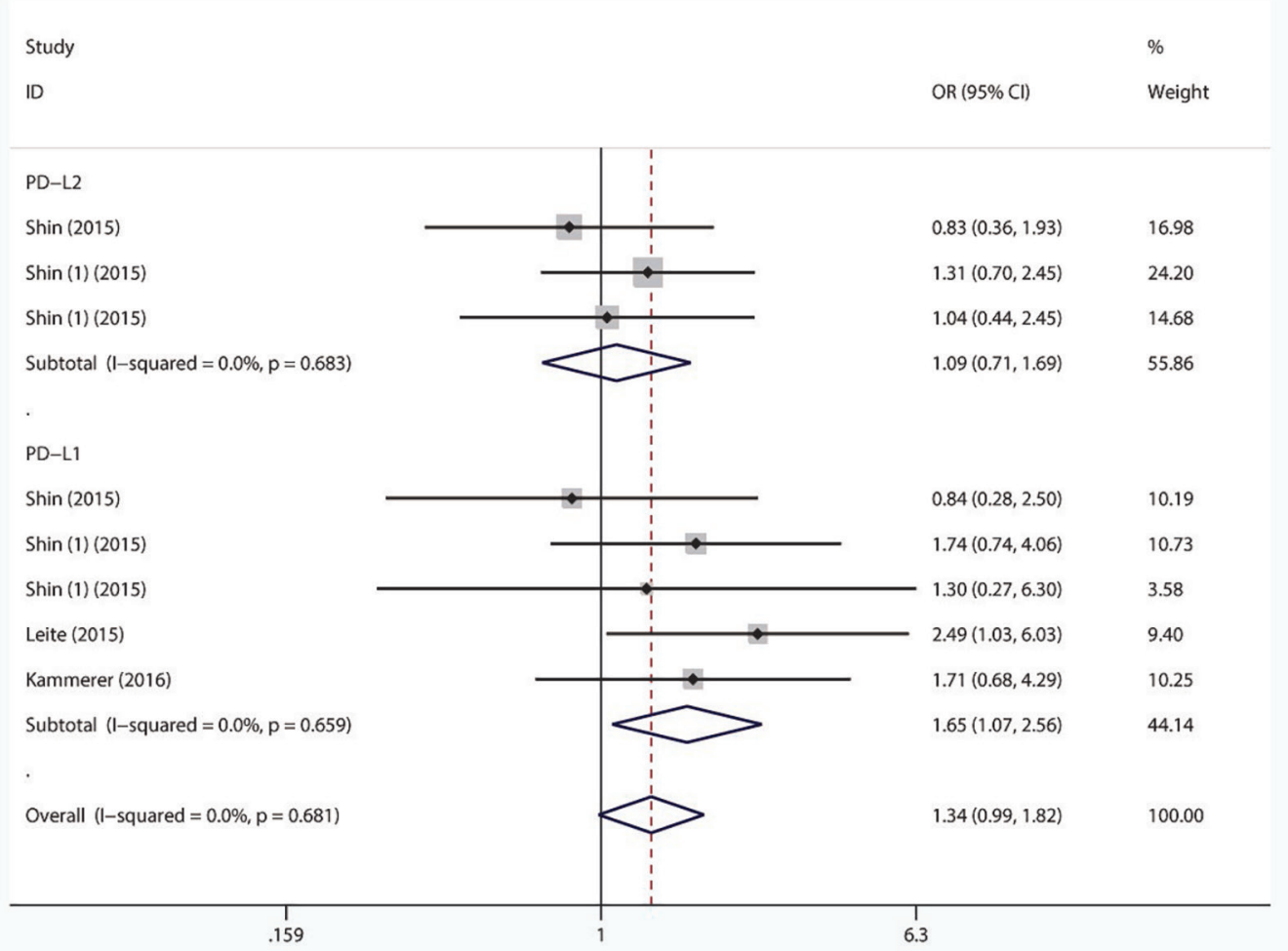

Figure S6 Correlation between PD-L1/2 expression and vascular invasion of RCC. RCC, renal cell carcinoma; PD-L1/2, programmed cell death ligand $1 / 2$. 


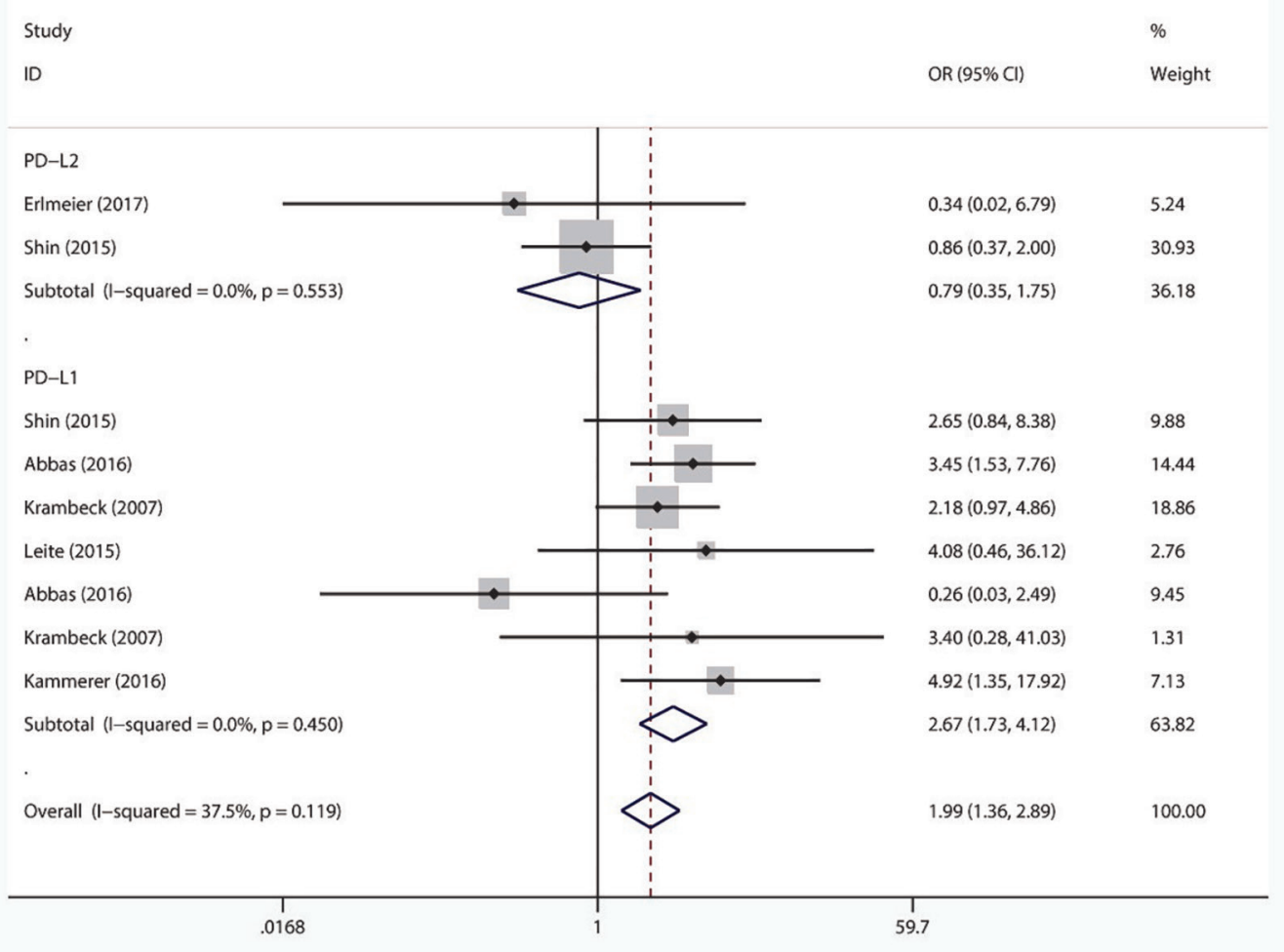

Figure S7 Correlation between PD-L1/2 expression and tumor metastasis of RCC. RCC, renal cell carcinoma; PD-L1/2, programmed cell death ligand $1 / 2$.

\begin{tabular}{|c|c|c|}
\hline \multicolumn{2}{|l|}{ Study } & \multirow{2}{*}{$\begin{array}{l}\% \\
\text { Weigh }\end{array}$} \\
\hline ID & OR $(95 \% \mathrm{Cl})$ & \\
\hline \multicolumn{3}{|l|}{ PD-L2 } \\
\hline Erlmeier (2017) & $1.17(0.40,3.49)$ & 3.46 \\
\hline Shin (2015) & $1.57(0.59,4.14)$ & 3.81 \\
\hline Shin (1) (2015) & $1.05(0.56,1.99)$ & 10.66 \\
\hline Shin (1) (2015) & $1.42(0.76,2.65)$ & 9.24 \\
\hline Zhang (2019) & $1.75(0.80,3.80)$ & 5.77 \\
\hline Subtotal $(I-$ squared $=0.0 \%, p=0.882)$ & $1.35(0.96,1.90)$ & 32.94 \\
\hline \multicolumn{3}{|l|}{. } \\
\hline \multicolumn{3}{|l|}{ PD-L1 } \\
\hline Shin (2015) & $0.41(0.13,1.25)$ & 5.00 \\
\hline Shin (1) (2015) & $0.69(0.29,1.64)$ & 6.67 \\
\hline Shin (1) (2015) & $0.59(0.18,1.94)$ & 3.77 \\
\hline Abbas (2016) & $0.30(0.14,0.64)$ & 13.53 \\
\hline Krambeck (2007) & $0.96(0.55,1.65)$ & 15.09 \\
\hline Leite (2015) & $0.73(0.29,1.84)$ & 6.10 \\
\hline Abbas (2016) & $1.30(0.43,3.98)$ & 3.10 \\
\hline Krambeck (2007) & $1.07(0.26,4.43)$ & 2.11 \\
\hline Zhang (2019) & $0.63(0.32,1.24)$ & 11.70 \\
\hline Subtotal $(I-$ squared $=6.7 \%, p=0.379)$ & $0.68(0.51,0.90)$ & 67.06 \\
\hline . & & \\
\hline Overall (I-squared $=32.1 \%, p=0.119$ ) & $0.90(0.73,1.11)$ & 100.00 \\
\hline $\begin{array}{c}1 \\
.132\end{array}$ & $\begin{array}{ll}1 \\
7.56\end{array}$ & \\
\hline
\end{tabular}

Figure S8 Correlation between PD-L1/2 expression in RCC and gender. RCC, renal cell carcinoma; PD-L1/2, programmed cell death ligand $1 / 2$. 